\title{
SOCIAL FACTORS IN THE AETIOLOGY OF NEPHRITIS IN CHILDHOOD
}

\author{
BY \\ NORMAN S. CLARK \\ From the Department of Child Health, University of Aberdeen
}

(RECEIVED FOR PUBLICATION FEBRUARY 6, 1956)

In view of the fact that nephritis is so often preceded by infection, usually in the upper respiratory tract, it is to be expected that factors favouring the spread of respiratory infection will also raise the incidence of nephritis. A recent study of nephritis in childhood has produced evidence that the incidence rises quite steeply as we descend the social scale and suggests that overcrowding is the feature of poverty which is most likely to be significant. As little has been published on this aspect of the aetiology of nephritis the results of this study are presented here.

\section{Case Material}

The case material for this study, consisting of 265 consecutive cases of nephritis admitted to the Royal Aberdeen Hospital for Sick Children between April, 1934, and May, 1952, has been briefly described in a previous paper (Clark, 1956).

\section{Incidence in Relation to Social Class}

In 130 cases it is impossible from the information in the notes to assess the social status of the father with certainty. In a further 16 cases the child was maintained by the mother alone because of illegitimacy, or death or divorce of the father. Table 1 shows the distribution of the remaining 119 cases according to the social class of the father (General Register Office, 1951).

TABLE 1

INCIDENCE AND SOCIAL CLASS

\begin{tabular}{|c|c|}
\hline Social Class & Number of Cases \\
\hline $\begin{array}{l}\text { I } \\
\text { II } \\
\text { III } \\
\text { IV } \\
\text { V }\end{array}$ & $\begin{array}{r}0 \\
12 \\
28 \\
37 \\
42\end{array}$ \\
\hline Total & 119 \\
\hline
\end{tabular}

Perusal of the addresses from which the remaining children were admitted suggests that the 119 cases are probably a fairly representative sample of the whole series in respect of social class.

According to the Annual Reports of the RegistrarGeneral for Scotland (1946 to 1952 - the only years for which the figures for total births are analysed according to social class), the ratio of births in the five social classes in Scotland is of the order of 3, $10,53,21,12$, and it is obvious, therefore, that an unduly high proportion of these cases of nephritis came from social classes IV and V. Where the home circumstances are poor, this will, of course, weigh heavily with the family doctor in his decision on whether the child should be admitted to hospital or not, and it is always difficult to assess to what extent this will bias the hospital figures in favour of cases from the lower social classes. The excess of cases in social classes IV and V shown in Table 1 is so great, however, that I find it difficult to believe that it does not, in part at least, represent a real increased incidence of nephritis in these social classes.

I have found no comparable series of cases of nephritis in which the incidence in relation to social class is discussed, but Hewitt and Stewart (1952) found a similar social gradient in the incidence of acute rheumatism in childhood, a finding of some interest in view of the relationship of both diseases to streptococcal infection. After careful study of the social factors involved in 793 Sheffield children suffering from a first attack of acute rheumatism they found no evidence that the disease was related to bad housing or poverty per se and concluded that the increased exposure to infection associated with large families and overcrowded homes might be responsible for the social gradient observed. This view and its applicability to nephritis will be further discussed in the next section.

\section{Incidence in Town and Country}

Of the 265 cases, 160 lived in the City of Aberdeen and 74 in the remainder of the County of Aberdeen. 
Thirty-one came from outside Aberdeenshire. When these figures are related to the respective populations of the City and County of Aberdeen, a marked difference in incidence is seen.

A study of the Annual Reports of the RegistrarGeneral for Scotland shows that throughout the period of the survey there has been a steady tendency for the population of the City to rise and for the population of the remainder of the County to fall. While there have been some fluctuations from time to time, it is probably sufficiently accurate for the present purpose to take as the population of each area the average of the figures for the first and the last years of the survey. Table 2 shows the population figures and the number of cases of nephritis over the whole period per 100,000 of the population.

TABLE 2

INCIDENCE IN CITY AND COUNTY OF ABERDEEN

\begin{tabular}{|c|c|c|c|c|c|}
\hline & \multicolumn{3}{|c|}{ Population } & \multirow{2}{*}{$\begin{array}{c}\text { Cases of } \\
\text { Nephritis } \\
\text { in } \\
\text { Children }\end{array}$} & \multirow{2}{*}{$\begin{array}{c}\text { Cases per } \\
100,000 \\
\text { Total } \\
\text { Popula- } \\
\text { tion }\end{array}$} \\
\hline & 1934 & 1952 & \begin{tabular}{|l|} 
Average \\
for 1934 \\
and 1952
\end{tabular} & & \\
\hline $\begin{array}{l}\begin{array}{l}\text { City of } \\
\text { Aberdeen } \\
\text { Remainder of } \\
\text { County of } \\
\text { Aberdeen }\end{array} \\
\end{array}$ & $\begin{array}{l}171,918 \\
148,210\end{array}$ & $\begin{array}{l}183,626 \\
143,056\end{array}$ & \begin{tabular}{|c|}
177,772 \\
145,633
\end{tabular} & 160 & 90 \\
\hline
\end{tabular}

While this table offers a useful means of comparison between the two areas it does not, of course, give any indication of the absolute frequency of nephritis in children in either town or county, for the cases of nephritis are drawn only from children under 12 years of age and not from the total population. Its validity as a means of comparison, therefore, depends on the assumption that the proportion of children in the two populations is approximately the same. Figures for the actual child population are readily available for two years only, 1948 (Craig and Burrell, 1950) and 1951 (General Registry Office, Edinburgh, 1953). These figures show that children under 12 years of age constituted $18.5 \%$ of the total population of the City in 1948 and $18.7 \%$ in 1951 , while the corresponding figures for the remainder of the County were $21.3 \%$ and $21.7 \%$. If this proportion of children in the two populations has remained constant throughout the period of this survey the true difference in incidence of nephritis between town and county children must be rather greater than the figures in Table 2 suggest.

It may be suggested that in the City there is a greater tendency to make use of the hospital services because of their proximity and that in consequence a higher proportion of the total cases are sent to hospital from the City than from the County. It is obvious that this does not explain the observed difference in incidence if we consider the number of cases admitted from Fraserburgh and Peterhead, the only towns in Aberdeenshire with populations of over 10,000, apart from the City of Aberdeen itself. The combined population of these two towns has remained virtually static during the period of the survey, the average for the years 1934 and 1952 being 23,125 . From this population 21 children have been admitted with nephritis, an incidence of 91 per 100,000 , practically the same as the figure for Aberdeen City.

If we now consider the figures for the County of Aberdeen after excluding the towns of Fraserburgh and Peterhead as well as the City of Aberdeen, we find that 53 children have been admitted with nephritis out of a total population of 122,508 , an incidence of 43 per 100,000 . It thus appears that, in this region, nephritis is at least twice as common in children living in a city or town as in children from rural surroundings.

I have found no previously reported series of cases of nephritis analysed according to place of residence, but Hewitt and Stewart (1952) have reported a similar high incidence of acute rheumatism in city children. In a study of the notification rates in certain regions of England where notification of acute rheumatism is compulsory, they found that the annual rate in Sheffield was between two and three times the rate in a rural area of Lincolnshire. As they point out, 'the variation exhibits the polarity usually found in infectious diseases, with the highest risk in the most densely populated area and the lowest risk in the most dispersed community'. Thus the present series of cases of acute nephritis and Hewitt and Stewart's cases of acute rheumatism bear a close resemblance to one another in respect both of incidence in relation to social class and of incidence in relation to urban versus rural domicile. As mentioned above they concluded that overcrowding with consequent increased exposure to infection was the most important factor in determining the distribution of their cases, and it is reasonable to suggest that the same factor is at work in the case of nephritis. Details of the home circumstances are unfortunately not available in the majority of my cases, but an interesting parallel emerges when we compare the relative incidence of nephritis as shown in Table 2 with the relative frequency of overcrowding in the areas concerned. Table 3 shows the figures for the incidence of nephritis in Aberdeen City, the remainder of Aberdeenshire and the towns of Fraserburgh and Peterhead compared with figures indicative of the 
frequency of overcrowding derived from the 1951 census figures (General Registry Office, Edinburgh, 1953).

From this table it is clear that Fraserburgh and Peterhead resemble Aberdeen City not only in the incidence of nephritis but also in the incidence of overcrowding and that in both respects the rural areas present a very different picture.

TABLE 3

INCIDENCE OF NEPHRITIS IN RURAL AND URBAN AREAS OF ABERDEENSHIRE

\begin{tabular}{|c|c|c|c|c|}
\hline & \multirow{2}{*}{$\begin{array}{c}\text { Cases of } \\
\text { Childhood } \\
\text { Nephritis } \\
\text { per } 100,000 \\
\text { Total } \\
\text { Population }\end{array}$} & \multicolumn{2}{|c|}{$\begin{array}{c}\text { Percentage of } \\
\text { Households } \\
\text { Occupying }\end{array}$} & \multirow{2}{*}{$\begin{array}{l}\text { Percentage } \\
\text { of House- } \\
\text { holds con- } \\
\text { taining } \\
\text { More than } \\
2 \text { Persons } \\
\text { per Room }\end{array}$} \\
\hline & & $\stackrel{1}{\text { Room }}$ & $\begin{array}{c}2 \\
\text { Rooms }\end{array}$ & \\
\hline $\left.\begin{array}{l}\text { Aberdeen City } \\
\text { Remainder of } \\
\quad \text { Aberdeen County } \\
\text { Fraserburgh } \\
\text { Peterhead }\end{array}\right\}$ & $\begin{array}{l}90 \\
51 \\
91\end{array}$ & $\begin{array}{r}9 \cdot 9 \\
3 \cdot 8 \\
13 \cdot 1 \\
9 \cdot 0\end{array}$ & $\begin{array}{l}28 \cdot 2 \\
13 \cdot 2 \\
26 \cdot 1 \\
25 \cdot 1\end{array}$ & $\begin{array}{r}8 \cdot 1 \\
4 \cdot 9 \\
12 \cdot 9 \\
10 \cdot 8\end{array}$ \\
\hline
\end{tabular}

It is generally accepted that respiratory infection, and in particular streptococcal infection, is the precipitating cause of most cases of nephritis and it seems highly probable that intimate contact is the most important factor favouring the spread of such infections (Dingle, Rammelkamp and Wannamaker, 1953); it seems reasonable, therefore, to conclude that the higher incidence of nephritis found in the larger towns and in the lower social classes is related mainly, if not entirely, to the frequency of overcrowding.

\section{Summary}

It is shown that, of children admitted to hospital with nephritis in north-east Scotland, an unduly high proportion come from families belonging to social classes IV and V.

It is further shown that the incidence of nephritis among country-dwelling children is only half that in children living in the City of Aberdeen or in the only two towns in the region with populations of over 10,000. The incidence of nephritis is closely paralleled by the incidence of overcrowding in the respective areas, and it is suggested that overcrowding, with resulting increased opportunities for the spread of infection, is the aspect of poverty which is most likely to be responsible for the higher incidence of nephritis in children from poorer homes.

\section{REFERENCES}

Clark, N. S. (1956). Archives of Disease in Childhood, 31, 12.

Craig, J. and Burrell, J. (1950). Paediatrics in the North-Eastern (Aberdeen) Region of Scotland, p. 9. Aberdeen.

Dingle, J. H., Rammelkamp, C. H., jun. and Wannamaker, L. W. (1953). Lancet, 1, 736.

General Register Office (1951). Classification of Occupations 1950. H.M. Stationery Office, London.

General Registry Office, Edinburgh (1953). Census, 1951. Report on the Fifteenth Census of Scotland, Vol. 1, parts 3 and 5 , Tables 24 and 25 . H.M. Stationery Office, Edinburgh. Tables 24 and 25. H.M. Stationery Office, Edinburgh.
Hewitt, D. and Stewart, A. (1952). Brit. J. soc. Med., 6, 161 . Registrar-General for Scotland, Annual Reports 1934 to 1952. H.M. Stationery Office, Edinburgh. 